\title{
Electrochemical Study of Novel 3-(6-bromo-2-oxo-2H- chromen-3yl-amino)-2-(3-chloro-phenyl)-thiazolidine- 4-one by Cyclic Voltammetry and its DNA Interaction Study by UV-Visible Spectroscopy
}

\author{
SHWETA SAXENA*, RATNESH DAS and ARTI SAXENA \\ Department of Chemistry, Dr. Hari Singh Gour Central University, Sagar M.P, India \\ shwetasaxena712@gmail.com
}

Received 31 July 2015 / Accepted 12 August 2015

\begin{abstract}
The electrochemical behaviour of 3-(6-bromo-2-oxo-2H-chromen-3yl-amino)-2-(3chloro-phenyl)-thiazolidine-4-one and its interaction with salmon sperm fish DNA was investigated. Electrochemical study of these compounds done in $0.1 \mathrm{~mol} \mathrm{~L}^{-1} \mathrm{BR}$ buffer (Britton Robinson) and $0.1 \mathrm{M} \mathrm{LiCl}$ used as a supporting electrolyte by cyclic voltammtery. CV study reveals that synthesized compound show one electron diffusion control, irreversible reduction peak. The diffusion coefficients of these derivatives were also calculated, after that DNA-interaction study done by UV-Visible spectrophotometer that show coumarin interacts with DNA via electrostatic mode involving outside edge stacking interactions with the oxygen atom of the phosphate backbone of DNA and the result of these type of interaction are denaturation of DNA strand which seem by hyperchromism in the emission spectra of these complex. Binding/association constants of these complexes were also calculated.
\end{abstract}

Keywords: 3-[2-Oxo-2H-chromen-3yl)amino]- 2- aryl 1, 3 Thiazolidine-4-one, Cyclic voltammtery, UV-Visible spectroscopy

\section{Introduction}

Coumarins are an important class of naturally occurring compounds which have been identified in plants and fungals. Many of them also have been synthesized and studied for their pharmacological activities ${ }^{1-4}$. A literature survey revealed numerous reports on the antiproliferative and antitumor activities of a variety of coumarin compounds ${ }^{5}$. These compounds have also been reported in clinical trials to demonstrate activity against prostate cancer, malignant melanoma, and metastatic renal cell carcinoma ${ }^{6-8}$. In addition, it is found that, some of them have anticoagulant activity. Coumarin is a sweet clover by molds, such as Penicillium nigricans and Penicillium jensi ${ }^{9}$. It is also used in biochemical experiments as an inhibitor of reductases ${ }^{9}$. 
There has been considerable interest in the binding studies of small molecules with DNA owing to their diverse applications ${ }^{10}$. DNA is the pharmacological target of many drugs that are currently in clinical use or are in advanced clinical trials ${ }^{11-12}$. DNA has been the recognition and characterization site for the interaction of small molecules as they yield effective information for the development of therapeutic agents for controlling gene expressions $^{13-14}$. Studying the interaction of pharmaceutical agents with DNA is also essential for understanding their mode of action and structural specificity of their binding reactions ${ }^{15}$. Interaction between small molecules and DNA provides a structural guideline in rational drug designing. It helps in the synthesis of new and improved drug entities with more selective activity, greater clinical efficacy and lower toxicity.

Small molecules may bind to DNA double helical structures through three different modes (i) electrostatic binding: occurs due to interaction between negatively charged DNA phosphate backbone and positively charged end of small molecules (ii) intercalative binding: occurs when small molecules intercalate within stacked base pairs thereby distorting the DNA backbone conformation ${ }^{16}$ (iii) groove binding: occurs due to hydrogen bonding or van der Waals interaction with nucleic acid bases and small molecules in the deep major groove or the shallow minor groove. Groove binders cause no or little distortion of the DNA backbone ${ }^{17}$. However, many small molecules can directly interact with DNA and the factors for these interactions are quite complex. Studying DNA as a drug target is attractive due to the availability of the genome sequence, well-studied three-dimensional DNA structure and the predictability of their accessible chemical functional groups. However, the number of known DNA-based drug targets is still very limited as compared to the protein-based drug targets ${ }^{18}$.

Coumarin(1,2-benzopyrone), the parent molecule of coumarin derivatives, is the simplest compound of a large class of naturally occurring polyphenolic substances made of fused benzene and apyrone rings ${ }^{19}$. Coumarin is present in a wide variety of plants including cassia, lavender, yellow sweet clover, tonka beans, green tea, woodruff and in fruits such as bilberry and cloudberry. Coumarins have recently attracted much attention because of their broad pharmacological properties. Coumarin has been reported to exhibit antioxidant, anti inflammatory, anti-mutagenic and anti-cancer properties ${ }^{20-22}$. Inspite of vast pharmacological properties of coumarin, its mode of binding with DNA has not been elucidated. It is thus pertinent to study the interaction of coumarin with DNA to reveal how this compound may be further modified to enhance its biological activities. The source being natural dietary constituents, an understanding of the interactions of coumarin and other related derivatives has the potential to provide guidelines for the development of more potent compounds. Present study is concerned to give the information of redox behaviour of 3-(6-bromo-2-oxo- $2 \mathrm{H}$ chromen-3yl-amino)- 2-(3-chloro-phenyl)-thiazolidine-4-one by $\mathrm{CV}$ at carbon pest electrode and its interaction with deoxyribonucleic acid (DNA) by UV-Visible spectrophotometer.

\section{Experimental}

Chemicals purchased from Sigma-Aldrich, Himedia and used without purification. Melting point was determined by using open capillary tube melting point apparatus. The IR spectra were recorded on a FTIR Shimadzu-8400S spectrometer using $\mathrm{KBr}$ pellets. The ${ }^{1} \mathrm{H}$ NMR and ${ }^{13} \mathrm{C}$ NMR spectra were recorded on Varian 300 spectrometer taking TMS as standard and DMSO as a solvent. Sonication was done with the help of frontline sonicator (with a frequency of $22 \mathrm{KHz}$ with a normal power of $225 \mathrm{~W}$ ). The $\mathrm{pH}$ measurement was carried out by $\mu \mathrm{pH}$ system 361 digital $\mathrm{pH}$ meter. 


\section{Electrochemical cells and voltammetric parameters}

Voltammetric experiments were carried out using a Metrohm 797 V.A. Computrace (Swiss made). Cyclic voltammetry were carried out using a carbon paste electrode $(d=0.2 \mathrm{~cm})$ as working electrode, a Pt wire as a counter electrode and a $\mathrm{Ag} / \mathrm{AgCl}(3 \mathrm{M} \mathrm{KCl})$ as a reference electrode, in one-compartment electrochemical cell. Carbon paste electrode $(\mathrm{d}=0.2 \mathrm{~mm})$ were prepared by mixing graphite powder with paraffin wax in 3:7 ratio, then it was sonicated for $1 \mathrm{~min}$ in an ultrasound bath and again rinsed with water. After this mechanical treatment, the carbon pest electrode was placed in three cell system. This procedure ensured very reproducible experimental Systronics 2201 double beam UV-Visible spectrophotometer were used for performing drug-DNA interaction.

\section{Sample preparation}

For cyclic voltammetry (CV) solutions were prepared by mixing $7.0 \mathrm{~mL}$ of $0.01 \mathrm{M}$ stock solution and $1.0 \mathrm{~mL}$ of $0.1 \mathrm{M} \mathrm{LiCl}$ (as supporting electrolyte) and $2.0 \mathrm{~mL}$ of $0.1 \mathrm{~mol} \mathrm{~L}^{-1} \mathrm{BR}$ (Britton Robinson) buffer. Nitrogen gas was passed in the solution for $\sim 15$ minutes and thereafter, a blanket of nitrogen gas was maintained throughout the experiment. During the experiment solution was subjected to controlled potential electrolysis. For UV-Visible study Salmon fish sperm DNA was used without further purification, its concentration was identified spectrophotometrically using the molar absorption coefficient $\varepsilon_{277}=2480 \mathrm{c.m}^{-1}$ $\mathrm{mol}^{-1}$ but here known concentration are used that are $0.0016,0.00232,0.00476 \mathrm{M}$ and its 1.1,1.6,2.32,4.76 mL volume will taking for analysis.

Synthesis of 3-(6-bromo-2-oxo-2H-chromen-3yl-amino)- 2-(3-chloro-phenyl)thiazolidine-4-one

A mixture of compound 3-(2-aryl methylidene hydrazinyl)-2H-chromene-2-one ${ }^{27}$ and 0.011 mole of thioglycollic acid $\left(\mathrm{SHCH}_{2} \mathrm{COOH}\right)$ was heated under reflux for $4 \mathrm{~h}$ in dry benzene using Dean Stark trap. Excess benzene was evaporated in vaccum. The residue was triturated with saturated $\mathrm{NaHCO}_{3}$ until $\mathrm{CO}_{2}$ evaluation ceased and was then left to stand overnight. The solid thus obtained was filtered and washed with water.

FTIR (KBr) $\left(\mathbf{V}_{\max } \mathbf{c m}^{-1}\right): 1590\left(\mathrm{NH}_{2}\right), 1550(\mathrm{~N}-\mathrm{N}), 1100(\mathrm{C}-\mathrm{N}), \quad 1675(\mathrm{C}=\mathrm{C}), 3030(\mathrm{C}-\mathrm{H})$, 1575(C-C), 850-550 (C-Cl) , 690-515 (C-Br). ${ }^{1} \mathrm{H}$ NMR data - (ppm, 300MHz,TMS)-7.1-7.8 $(\mathrm{m}, 8 \mathrm{H}, \mathrm{Ar}-\mathrm{H}), 2.60(\mathrm{~s}, 1 \mathrm{H}, \mathrm{NH}), 6.51(\mathrm{~s}, \mathrm{C}-\mathrm{H}) .3 .24\left(\mathrm{~s}, 2 \mathrm{H}, \mathrm{CH}_{2}\right) \cdot{ }^{13} \mathrm{C}$ NMR data- (ppm, $100 \mathrm{MHz}, \mathrm{DMSO}) \delta \mathrm{ppm}: 162(\mathrm{C}=\mathrm{O}), 120-128(\mathrm{C}=\mathrm{C}), 56.9(\mathrm{CH}$ aliphatic $), 38.5\left(\mathrm{CH}_{2}\right.$ aliphatic $)$.

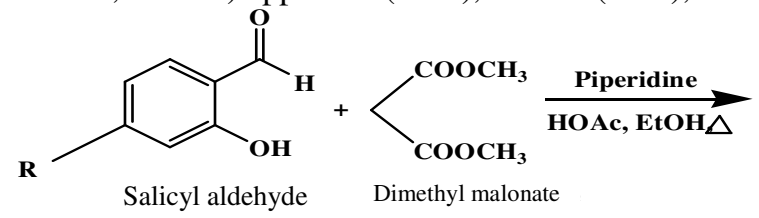<smiles>[Y]c1ccc2oc(=O)c(OC(C)=O)cc2c1</smiles>

Synthesis of 2-axo-2H-chromen-3yl-acetate<smiles>[X]c1ccc2oc(=O)c(OC(C)=O)cc2c1</smiles>

2-oxo-2H-chromen-3yl-acetate<smiles>[X]c1ccc2oc(=O)c(NN)cc2c1</smiles>

3-hydrazinyl 2H-chromen-2-one II a-c

Synthesis of 3-hydrazinyl $2 \mathrm{H}$-chromen 2-one 


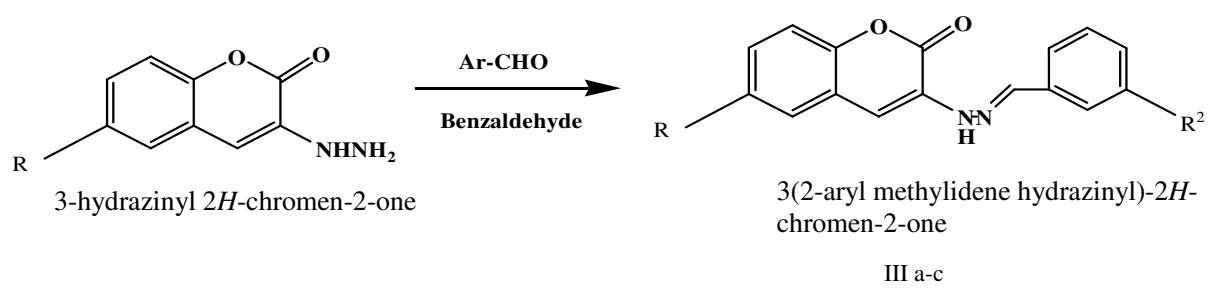

Synthesis of 3(2-aryl methylidene hydrazinyl)-2H-chromen-2-one
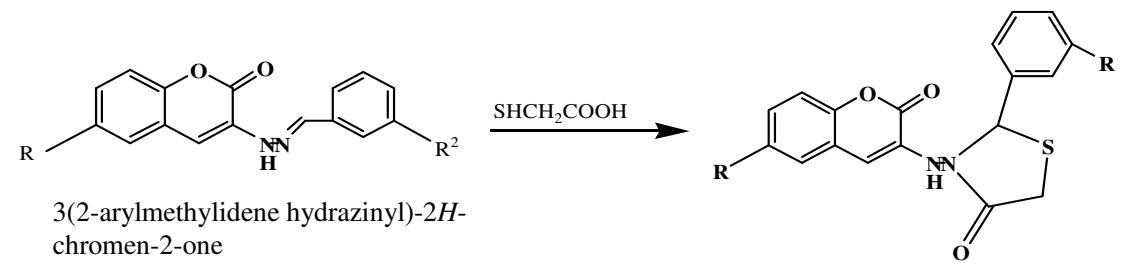

3(2-oxo-2H-chromen-3yl)amino]-2 aryl

1,3 Thiazolidine-4-one

$$
\text { IV } \mathrm{A}_{1}-\mathrm{D}_{5}
$$

Synthesis of 3[2-oxo- $2 H$-chromen-3y I)amino]-2 aryl 1,3 Thiazolidine-4-one

$$
\mathrm{R}=\mathrm{Br}, \mathrm{R}^{2}=\mathrm{Cl}
$$

Scheme 1. General scheme for the synthesis of 3-(6-bromo-2-oxo-2H-chromen-3yl-amino)2-(3-chloro-phenyl)-thiazolidine-4-one given below

\section{Results and Discussion}

\section{Cyclic voltammetric studies}

This paper explains the electrochemical behaviour of 3-(6-bromo-2-oxo- $2 H$-chromen-3ylamino)-2-(3-chloro-phenyl)-thiazolidine-4-one at a carbon paste electrode and this experiment were carried out in $0.1 \mathrm{~mol} \mathrm{~L}^{-1} \mathrm{BR}$ (Britton Robinson) buffer and $0.1 \mathrm{M} \mathrm{LiCl}$ as supporting electrolyte. Compound 3-(6-bromo-2-oxo-2H-chromen-3yl-amino)- 2-(3-chlorophenyl)-thiazolidine-4-one show voltammograms at $10 \mathrm{pH}$. During the voltammetric measurement a constant flux of $\mathrm{N}_{2}$ was kept over the solution surface in order to check the diffusion of atmospheric oxygen into the solution. In this study purging time is $10 \mathrm{Sec}$, deposition time is $60 \mathrm{~s}$ and deposition potential is $-1.100 \mathrm{~V}$. Several peaks were observed (Figure 2). A study of effect of scan rate is made in order to find out the feasibility of electrochemical reactions and linear plots of $\mathrm{I}_{\mathrm{pc}} v s . \mathrm{V}^{1 / 2}$ are obtained, that show the reduction of derivatives in this medium is diffusion controlled with increasing scan rate (Figure 1).

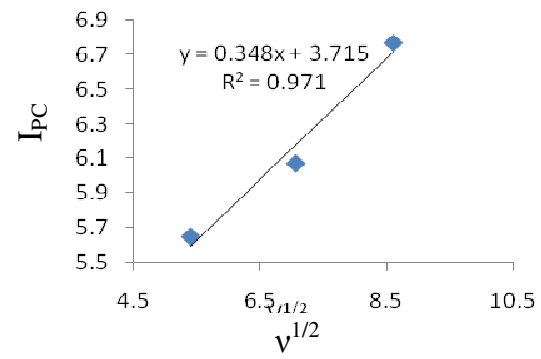

Figure 1. Plot of peak current $\left(I_{p c}\right)$ vs. square root of the sweep rate $\left(v^{1 / 2}\right)$ for 3-(6-bromo-2oxo-2 $H$-chromen-3yl-amino)- 2-(3-chloro-phenyl)-thiazolidine-4-one 
3-(6-Bromo-2-oxo-2H-chromen-3yl-amino)- 2-(3-chloro-phenyl)-thiazolidine-4-one

3-(6-Bromo-2-oxo-2H-chromen-3yl-amino)- 2-(3-chloro-phenyl)-thiazolidine-4-one shows one electron reduction peak on different scan rate. It's anodic half cycle and cathodic half cycle show one peak as mentioned in Table 1 and shown in Figure 2. Good linear plots of $I_{p c}$ $v s . v^{1 / 2}$ are obtained that show the reduction of 3-(6-bromo-2-oxo- $2 H$-chromen-3yl-amino)2-(3-chloro-phenyl)-thiazolidine-4-one in this medium is diffusion controlled with employed scan rate $\left(30,50\right.$ and $\left.75 \mathrm{mVs}^{-1}\right)$ in Figure 1. The shift of cathodic peak potential towards more positive values with the increase in scan rate indicates irreversible nature of the system $^{23}$. Peak current for irreversible system is given by Randle Sevick equation;

$$
\mathrm{I}_{\mathrm{pc}}=\left(2 \cdot 99 \times 10^{5}\right) \mathrm{n}\left(\alpha \mathrm{n}_{\mathrm{a}}\right)^{1 / 2} \mathrm{ACD}_{0}{ }^{1 / 2} v^{1 / 2}
$$

Where $\mathrm{A}$ is the area of electrode in $\mathrm{cm}^{2}, \mathrm{D}_{0}$ the diffusion coefficient in $\mathrm{cm}^{2} \mathrm{~s}^{-1}, \mathrm{C}$ the concentration in $\mathrm{mol} \mathrm{L}^{-1}$ and $v$ is in $\mathrm{mVs}^{-1}$.

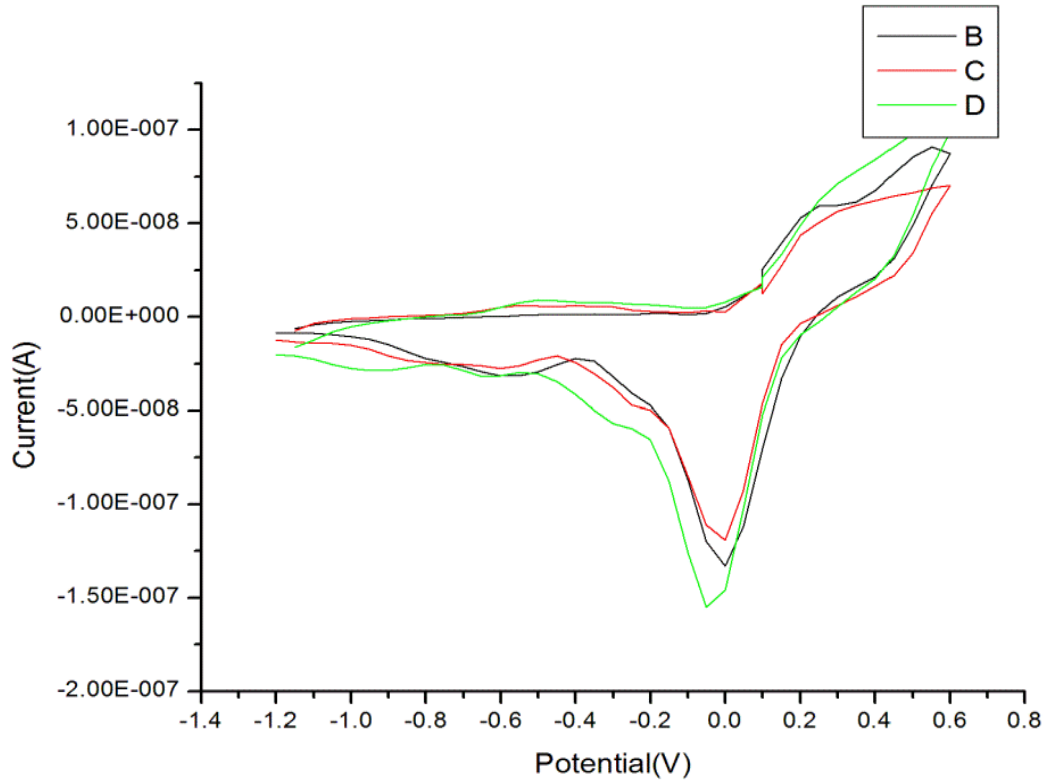

Figure 2. Cyclic voltammogram at different scan rate $\left(30,50\right.$ and $\left.75 \mathrm{mVs}^{-1}\right)$ of 3-(6-bromo2-oxo-2H-chrome-3yl-amino)- 2-(3-chloro-phenyl)-thiazolidine-4-one

Table 1. Electrochemical parameters of 3-(6-bromo-2-oxo-2H-chromen-3yl-amino)- 2-(3chloro-phenyl)-thiazolidine-4-one

\begin{tabular}{cccccc}
\hline$E p_{c}, \mathrm{mV}$ & $\mathrm{Ip}_{\mathrm{c}}, \mathrm{pA}$ & $\begin{array}{c}\text { Scan rate, } \\
\mathrm{mVs}^{-1}\end{array}$ & $E p_{a}, \mathrm{mV}$ & $\mathrm{Ip}_{\mathrm{a}}, \mathrm{pA}$ & $\begin{array}{c}\mathrm{D}_{0}{ }^{1 / 2} * 10^{-3}, \\
\mathrm{~cm}^{2} \mathrm{~s}^{-1}\end{array}$ \\
\hline 0.26062 & 5.65315 & 30 & -0.00466 & -1.17927 & 1.163 \\
\hline
\end{tabular}

Drug -DNA interaction study by UV-Visible spectroscopy

UV-Visible absorption spectroscopy is very useful technique for study the drug alone or interaction with others molecules they may be small or large. It is very simplest, reliable and most commonly employed technique for study the drug -polynucleotide interaction. Drugpolynucleotide interaction are based on the absorption phenomena in the UV spectroscopy 
means each molecule show maximum absorption at particular wavelength, when these molecule interact with other molecule which may be small or large show maximum absorption at different wave length so, by analyzing the changes in the absorption properties (including $\lambda_{\max }$ or intensity of band) of drug and the drug-DNA complex, we can find the type of interaction between them. Generally drug works as a ligand exhibit an absorption maxima that can easily recognize in the visible region an easy route for the determining the interaction between drug and polynucleotide (or protein or enzyme) is to scan the shifting the position of the absorption maximum when drug is free in the solution or when the drug is attached with polynucleotide. The magnitude of this displacing of the absorption band could explain as an signal for the analyzing the strength of the interaction between the DNA and drug molecule ${ }^{24-26}$.

Drug-polynucleotide(DNA) interaction are different type it could covalent or non covalent depends upon the force that present between them, which are identify by comparing the UV spectra of drug molecule and drug -DNA complex. If after interaction spectra show hypochromism and bathochromic shift (red shift) then its mean compound attached with DNA through intercalation. Degree of hypochromism is depends on the strength of intercalation ${ }^{27}$ and strength of intercalation depends on the distance between DNA and drug molecule, when distance decrease then intensity of absorption band decrease result an hypochromic shift and in this case difference between $\pi$ bonding and $\pi^{*}$ energy level also decrease, so electron transition from $\pi$ bonding orbital of drug to $\pi^{*}$ orbital of polynucleotide easily takes place then result a red or bathochromic shift ${ }^{28-29}$.

On other hand hyperchromic effect is observed when drug molecule attach with DNA by electrostatic attraction( presence of cation), hyperchromism also reflect the structural or conformational changes in DNA molecule after binding with drug molecule, this phenomena occur due to presence of charged cation in the drug molecule, charge cation bind with more electro negative oxygen atom of phosphate group present on DNA back bone by electrostatic attraction ${ }^{30}$ then hydrogen bonding between purine and pyrimidine base disrupted (A and T, G and C) and DNA denaturation takes place, by DNA denaturation purine and pyrimidine base are free as a result surface area (active site) increase so, the absorption intensity of band extremely increase about $40 \%$ more than free double strand DNA at the same concentration.

On the bases of maximum absorption in free drug and drug combine with DNA we can find out the binding /association constant of the drug with DNA according to BenesiHildebrand equation ${ }^{31}$.

$$
\mathrm{A}_{0} / \mathrm{A}-\mathrm{A}_{0}=\varepsilon_{\mathrm{D}} / \varepsilon_{\mathrm{D}-\mathrm{D}}-\varepsilon_{\mathrm{D}}+\varepsilon_{\mathrm{D}} / \varepsilon_{\mathrm{D}-\mathrm{D}}-\varepsilon_{\mathrm{D}} * 1 / \mathrm{K}_{\mathrm{b}}[\mathrm{DNA}]
$$

Where $\mathrm{K}_{\mathrm{b}}$ is the association /binding constant, $\mathrm{A}_{0}$ and $\mathrm{A}$ are the absorbance of drug and its complex with DNA, respectively and $\varepsilon_{\mathrm{D} \text { and }} \varepsilon_{\mathrm{D}-\mathrm{D}}$ are the absorption coefficient of the drug and the DNA- drug complex, respectively. The association constant can be determined from the intercept-to-slope ratios of $\mathrm{A}_{0} / \mathrm{A}-\mathrm{A}_{0} v s .1 /[\mathrm{DNA}]$ plot.

Figure 3 Show the interaction of 3-(6-bromo-2-oxo-2H-chromen-3yl-amino)- 2-(3chloro-phenyl)-thiazolidine-4-one with DNA, this show with increasing concentration of DNA in the drug solution the intensity of absorption band increase and $\lambda_{\max }$ also affected, so the consequence of DNA addition is hyperchromism. Figure 4 represents the plot between A0/A-A0 vs. 1/[DNA], with the help of this plot we can determine the binding constant of Drug-DNA complex i.e. $\mathrm{K}_{\mathrm{b}}=1.28 * 10^{4} \mathrm{M}^{-1}$. 


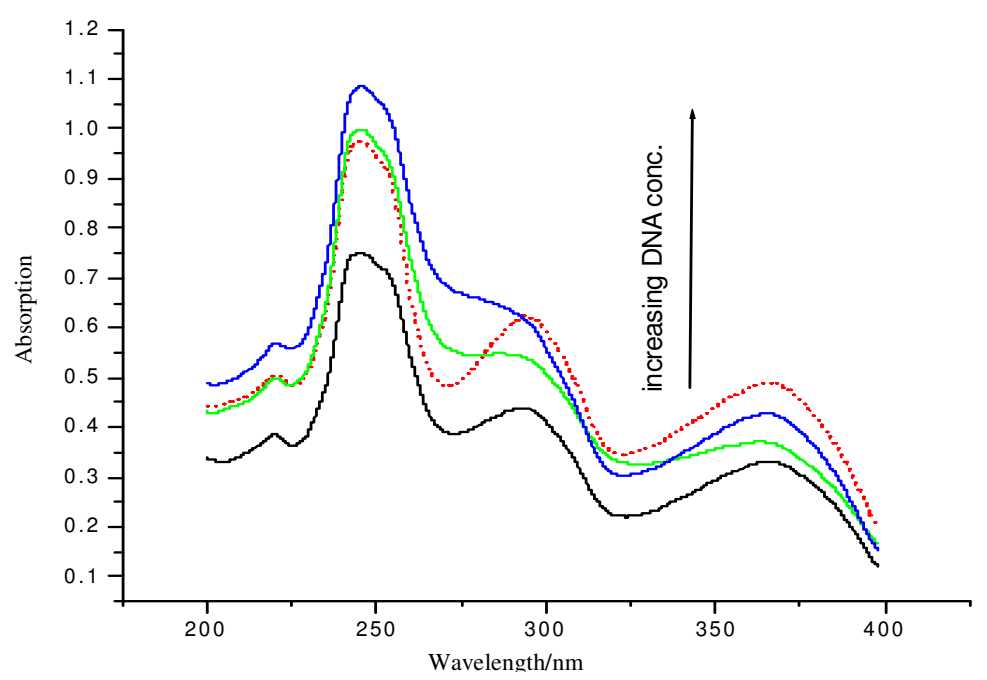

Figure 3. UV visible absorption spectra of 3-(6-bromo-2-oxo- $2 H$-chromen-3yl-amino)- 2(3-chloro-phenyl)-thiazolidine-4-one and arrow represent the increasing concentration of DNA in the solution

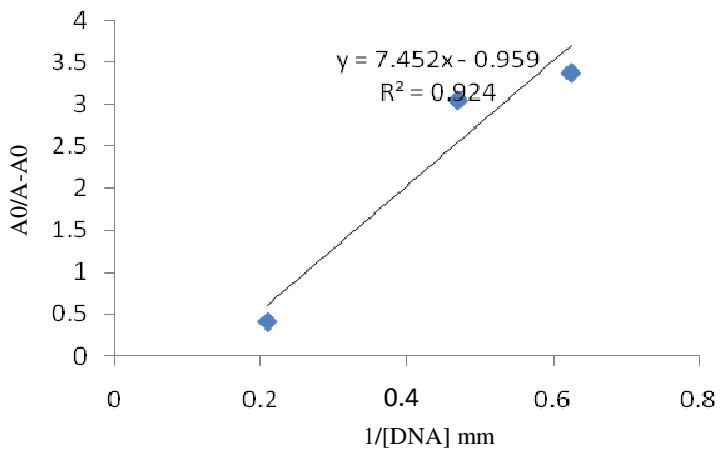

Figure 4. Graph between $\mathrm{A}_{0} / \mathrm{A}-\mathrm{A}_{0}$ vs. 1/[DNA] plot

\section{Conclusion}

Electrochemical studies revealed that 3-(6-bromo-2-oxo-2H-chromen-3yl-amino)- 2-(3-chlorophenyl)-thiazolidine-4-one are electro active as it undergoes oxidation and reduction processes at a carbon paste electrode. Compound show one electron irreversible reduction. Diffusion coefficient $\mathrm{D}_{0}{ }^{1 / 2}$ for compound (6-bromo-2-oxo- $2 \mathrm{H}$-chromen-3yl-amino)- 2-(3-chloro-phenyl)thiazolidine-4-one is $1.163 * 10^{-3} \mathrm{c.m} .{ }^{2} \mathrm{~s}^{-1}$. Drug-DNA complex interaction has been investigated by UV-Visible spectroscopy. All spectral data and figure indicate that interaction between DNA and drug complexes takes place. In the drug 3-(6-bromo-2-oxo- $2 H$-chromen3yl-amino)- 2-(3-chloro-phenyl)-thiazolidine-4-one bind to DNA via electrostatic mode involving outside edge stacking interactions with the oxygen atom of the phosphate backbone of DNA with binding constant $\mathrm{k}_{\mathrm{b}}=1.28 * 10^{4} \mathrm{M}^{-1}$ respectively, show hyperchromism.

\section{Acknowledgement}

I express my thanks to, Department of Chemistry, Dr. Harisingh Gour central University, Sagar (M.P) .The MPCST Bhopal, for the financial support in the form of research fellowship. 


\section{Reference}

1. Palaniappan S and Shekhar R C, J Mol Catal A: Chem., 2004, 209(1-2), 117-124; DOI:10.1016/j.molcata.2003.08.006

2. Batanero B, Pe'rez M J and Barba F, J Electroanal Chem., 1999, 469(2), 201-205; DOI:10.1016/S0022-0728(99)00198-9

3. Chang C J, Floss H G and Steck W, J Org Chem., 1977, 42(8), 1337-1340; DOI:10.1021/jo00428a014

4. Souza J D and Nagaraju N, Indian J Chem Technol., 2008, 15, 244-251.

5. Madari H, Panda D, Wilson L and Jacobs R C, Cancer Res., 2003, 63, 1214-1220, and the references cited therein.

6. Thornes R D, Daly L, Lynch G, Breslin B, Browne H, Browne H Y, Corrigan T, Daly P, Edwards G and Gaffney E, J Cancer Res Clin Oncol., 1994, 120(1), S32-S34; DOI:10.1007/BF01377122

7. Marshall M E, Butler K and Fried A, Mol Biother., 1991, 3, 170-178.

8. Mohler J L, Gomella L G, Crawford E D, Glode L M, Zippe C D, Fair W R and Marshall M E, Prostate, 1992, 20(2), 123-131.

9. Keating G J, Kennedy R O, in: Kennedy R O, Thornes R D, (Eds.), The Chemistry and Occurrence of Coumarins, Coumarins: Biology, Applications and Mode of Action, John Wiley \& Sons, West Sussex, England, 1997, pp. 23-64.

10. Yunus G, Srivastava S, Kuddus M and Gupta V D, Curr Appl Phys., 2013, 13(2), 322-326; DOI:10.1016/j.cap.2012.05.020

11. Opar A, Nat Rev Drug Discov., 2009, 8(6), 437-438; DOI:10.1038/nrd2916

12. Huang R, Wang L R and Guo L H, Anal Chim Acta, 2010, 676(1-2), 41-45; DOI:10.1016/j.aca.2010.07.033

13. Shi Y, Guo C, Sun Y, Liu Z, Xu F, Zhang Y, Wen Z and Li Z, Biomacromolecule., 2011, 12(3), 797-803; DOI:10.1021/bm101414w

14. Ding Y, Zhang L, Xie J and Guo R, J Phys Chem B, 2010, 114(5), 2033-2043; DOI:10.1021/jp9104757

15. Elder R M, Emrick T and Jayaraman A, Biomacromolecules, 2011, 12, 3870-3879; DOI:10.1021/bm201113y

16. Erkkila K E, Odom D T and Barton J K, Chem Rev., 1999, 99, 2777-2796; DOI:10.1021/cr9804341

17. Barone G, Terenzi A, Lauria A, Almerico A M, Leal J M, Busto N and García B, Coord Chem Rev., 2013, 257(19-20), 2848-2862; DOI:10.1016/j.ccr.2013.02.023

18. Berman H M, Westbrook J, Feng Z, Gilliland G, Bhat T N, Weissig H, Shindyalov I N and Bourne P E, Nucleic Acids Res., 2000, 28(1), 235-242; DOI:10.1093/nar/28.1.235

19. Borges F, Roleira F, Milhazes N, Santana L and Uriarte E, Curr Med Chem., 2005, 12(8), 887-916.

20. Kostova I, Bhatia S, Grigorov P, Balkansky S, Parmar V S, Prasad A K and Saso L, Curr Med Chem., 2011, 18, 3929-3951; DOI:10.2174/092986711803414395

21. Gacche R N and Jadhav S G, J Exp Clin Med., 2012, 4(3), 165-169; DOI:10.1016/j.jecm.2012.04.007

22. Witaicenis A, Seito L N, da Silveira Chagas A, de Almeida L D Jr, Luchini A C, Rodrigues-Orsi P, Cestari S H and Di Stasi L C, Phytomedicine, 2014, 21(3), 240246; DOI:10.1016/j.phymed.2013.09.001

23. Nicholson R S and Shain I, Anal Chem., 1964, 36(4), 706-723; DOI:10.1021/ac60210a007 
24. Sun H, Xiang J, Liu Y, Li L, Li Q, Xu G and Tang Y, Biochimie, 2011, 93, 13511356; DOI:10.1016/j.biochi.2011.06.007

25. Jaumot J and Gargallo R, Curr Pharmaceut Des., 2012, 18(14), 1900-1916; DOI:10.2174/138161212799958486

26. Wei C, Wang J and Zhang M, Biophys Chem., 2010, 148(1-3), 51-55; DOI:10.1016/j.bpc.2010.02.009

27. Das R and Saxena S, J Applicable Chem., 2014, 3(2), 595-600.

28. Liu J, Zhang T, Lu T, Qu L, Zhou H, Zhang Q and Ji L, J Inorg Biochem., 2002, 91(1), 269-276; DOI:10.1016/S0162-0134(02)00441-5

29. Sirajuddin M, Ali S, Haider A, Shah N A, Shah A and Khan M R, Polyhedron, 2012, 40(1), 19-31.

30. Sirajuddin M, Ali S, Shah N A, Khan M R and Tahir M N, Spectrochim Acta Part A: Mole Biomole Spectr., 2012, 94, 134-142; DOI:10.1016/j.saa.2012.03.068

31. Arjmand F., Jamsheera A., Spectrochim. Acta Part A: Mole Biomole Spectr., 2011, 78(1), 45-51; DOI:10.1016/j.saa.2010.06.009 